PROBLEMS

OF EDUCATION

IN THE $21^{\text {st }}$ CENTURY

Volume 57, 2013

\section{PRESERVING AFRICAN LANGUAGES AND TERRITORIAL INTEGRITY IN THE FACE OF EDUCATION AND GLOBALIZATION}

\author{
Ayodeji Olasunkanmi Abari, Idowu Olufunke Oyetola, \\ Adedapo Adetayo Okunuga \\ Lagos State University, Ojo, Nigeria \\ E-mail: ayodeji.abari@yahoo.com, funke.oyetola@yahoo.com, \\ agbeburu@yahoo.com
}

\begin{abstract}
With the colonization of Africa, the language of the colonial masters has taken precedence over the indigenous languages of the Africans to the extent that the latter seems to be going into extinction. Yet, education is better founded on the native language of a people which also preserves their culture and tradition and gives them their own separate identity. Meanwhile, the world has turned into a global village and there now exist international languages with the owners'ways of life. The latter seems to have subsumed the culture and tradition of others who are borrowers of the international language. Where then lays the fate of Africans, between the preservation of their indigenous languages and the risk of being left out and behind the rest of the world if they do not simultaneously come to terms with international languages. It is these issues of language and education, as well as globalization and African territorial integrity that this study examines separately and jointly with a view to juxtaposing them. The study then recommends balanced ways out of the dilemma one of which is the compulsory use of the mother tongue by Africans as the medium of instruction at the foundational level of education.
\end{abstract}

Key words: African languages, education, globalization, preserving, territorial integrity.

\title{
Introduction
}

With the advancement in science and technology these days, the world has already become a global village and the need for a common language or some common languages among nations is fast becoming realized and cannot be overemphasized. Today, English, French and Arabic are considered international languages the first of the three being the most widely spoken in the world. Some other languages are at the doorstep of becoming international such as the Chinese Language, again, because of their development in science and technology. Meanwhile, Africa cannot afford to be left out in the scheme of world affairs even if the countries in the continent would want to keep their identity and would not want their native languages to go into extinction. A good thing, having been differently colonized by the powers that be then, most African countries have one of these three languages as their lingua franca except perhaps a few such as Tanzania in East Africa where "the government is often praised for its successful promotion of a single indigenous language as the official national language" (Rabin, 2011). Thus, despite rhetoric and resolutions, the dominance of ex-colonial languages persists throughout the continent (Tanzania being among the notable exceptions) (Williams, 2004). This stands the many African countries in a good position to be part and parcel of the globalization process.

However, this seems to be taking place at the expense of their own indigenous languages which are playing the second fiddle in their activities particularly in education. The situation 
becomes more worrisome when it is observed that the indigenous languages are so relegated that some are at the threshold of extinction. Therefore, there can be no pretence about it that Africa and Africans are in a dilemma with respect to making use of a foreign language in the education of their citizens, giving their own languages their place of pride and remaining relevant in global affairs. How then can Africans preserve their indigenous languages for use in their education? How can they preserve their indigenous languages in the face of international languages and in the face of globalization? And, how would African territorial integrity be preserved where and if the peoples' indigenous languages are relegated and are at the threshold of extinction?

Apart from illustrating the importance of language in education, the response to these posers would also re-awaken the interest of scholars, particularly African scholars in the use of indigenous language as a medium of instruction. Yet, beyond questions, "the goal of appropriate language policies for effective education is worth pursuing, and while it does not behove outsiders to be too glib in their pronouncements, it is obvious to insiders and outsiders that current practices of over-reliance on exoglossic languages are failing individuals, their communities and their countries in Africa" (Williams, 2004). In addition, against the backdrop of constraining global forces, and Africa's internal problems (wars, repression, and general economic misery), it is the contention of this study that African languages could be the most critical element for Africa's survival, and cultural, educational and economic development. Thus the study brings to limelight the need for Africa to 'invest in this sector of 'cultural economy' as much as it does (should do) in the 'material economy' since both spheres are interrelated and impact on each other" (Negash, 2005).

\section{Language, Education and Society: Some Theoretical Considerations}

Language remains the only means by which education is actualized and customs and tradition transmitted from one generation to another. In addition and, according to Kiplangat (2003), languages serve as important symbols of belongings, enabling different groups of people to know what ethnic groups they belong to, and what common heritages they share. This means that without an indigenous language people would lose their cultural identity and most probably their origin.

Language can further be seen as one of the several inputs of the society into the school system. Instruction is given in a language shared by all. Thus, it is necessary to teach the language of instruction first in any educational programme. Language can also be defined as a generic, communication phenomenon especially in description of instruction. Language facilitates learning, through interaction with adults and collaboration with mates; children learn things they could not accomplish on their own, especially in a language. The teacher teaches, asks questions, orchestrates discussions and gives assignments via a language and through this the pupils learn to read and speak a particular language.

Language, especially a common one, enhances national and regional unity. A common language is usually native to the people as found in the advanced countries of the world and in regional entities in some other parts of the world particularly in Africa. However, language could also be foreign to a nation depending on the latter's historical antecedents, again, particularly in Africa. Meanwhile, stripping a society of its native language is like stripping it of its culture and heritage. Although, this is not saying that education is inhibited when a foreign language is learnt, research studies have shown that learning to read and write in one's native language provides a useful foundation for students learning to read and write in other languages. That is, education is better actualized using the medium of the mother tongue as the language of instruction. In their study, Taylor and Coetzee (2013) found out that "after including school fixed effects, which removes the confounding effects of selection into schools with different 
Ayodeji Olasunkanmi ABARI, Idowu Olufunke OYETOLA, Adedapo Adetayo OKUNUGA. Preserving African Languages and Territorial Integrity in the Face of Education and Globalization

PROBLEMS

OF EDUCATION

IN THE $21^{\text {st }}$ CENTURY Volume 57, 2013

10 language policies, mother-tongue instruction in the early grades significantly improves English acquisition, as measured in grades 4,5 and 6". This is in line with pedagogical theory which promotes the acquisition of a first language before moving on to a second language (Taylor and Coetzee, 2013). Williams (2004) puts it this way that, "the ubiquitous rhetoric of "child centred education' is vacuous where the child's language - the very tool which allows one to 'centre' on the child - is set aside...." Thus, UNESCO (2013) "promotes mother tongue-based bilingual or multilingual approaches in education as an important factor for inclusion and quality in education". Again, research shows this has a positive impact on learning and learning outcomes.

The significance of education in the life of an individual and of the society can also never be quantified or qualified. Not only does education enable the acquisition of knowledge and skills, it also helps in the transmission of societal values, norms, tradition and culture from one generation to the other thereby giving room to posterity. Education further stands out as the very mechanism that a society uses not only to create an identity for itself but also to attain self recognition in the global scheme of affairs. The more reason education is seen as an agent of modernization that helps a society to preserve and transmit its characteristics and also helps in the acquisition of new knowledge and skills necessary to survive and make progress in a human society (Ethusani, 2002). Education can then be equated to the key that unlocks the development of personal and societal potentials. It is equally an indispensable tool for enhancing economic growth and sustainable national development. It is the cornerstone of development in all its ramifications forming the basis for literacy and numeracy, skill acquisition, technological advancement and societal integration as well as the ability to harness the natural resources of the state, human, mineral and material.

Most African governments have therefore adopted education as an instrument per excellence for effecting social and economic development, an instrument for inculcating values of respect for the worth and dignity of individuals, giving the students the ability to make rational decisions, and have moral and spiritual values in interpersonal and shared responsibility for the common goals of the society (FRN, 2004). That notwithstanding, education in Africa still remains a subject of foreign languages whereby African indigenous languages are taught and learnt as a second language. The question is then reiterated as to what Africans can do and how they can preserve their indigenous languages from going into extinction even where and if they have to partake in global affairs in foreign languages. Meanwhile:

Lack of political will in the implementation of pre-language policies remains widespread throughout Africa, from Nigeria to Kenya, to South Africa. In Rwanda, it would seem priority is being given to English and French rather than the population's common language, Kinyarwanda, while Malawi is said to be considering reducing the role of the widely-spoken national language, Chichewa, as a medium of instruction at primary level in favour of English (Williams, 2004)

\section{Globalization, African Languages and Territorial Integrity}

Globalization is the process of international integration arising from the interchange of world views, products, ideas and other aspects of culture (Al-Rodhan, Nayef and Stoudmann, 2006). Globalization can also be seen as the process of developing and increasing world-wide exchange of cultural and traditional resources and ideas. All of these involve interactions and interrelations in a particular language common to parties involved. With globalization pushing into pre-eminence a particular language other than the indigenous languages especially in Africa, is to deal a death blow on the culture of the people of Africa and, as the local languages of Africa gradually fade away, the local culture gradually nose dive into extinction.

A ready example is the English Language, the language most commonly associated with globalization, often disparagingly (Corbin, 2007), and the language which is paramount in Afri- 
ca because of the large areas colonized by the English people. English is a dominant and global language, used more globally in business, media, internet, and academia. Other languages are

PROBLEMS

OF EDUCATION

IN THE $21^{\text {st }}$ CENTURY

Volume 57, 2013 pushed to the background because of English domination of both local and international business and media. English is also used in schools and local markets. Indeed, it is used as the lingua franca of such nations.

English Language can be considered a global language and no other language dominates the international scene as it does. Thus Corbin (2007) observes that "while there are more Chinese speakers in the world (combining all of its various dialects), English is spoken in more countries and more often as a second language than any other, and its use continues to grow". This dominance is encouraged by the fact that English has become a popular language for international scientific publications (Li, 2002). Again, as observed by Corbin (2007), "in 1997, the Science Citation Index reported that 95 percent of its articles were written in English, even though only half of them came from authors in English-speaking countries". This helps to spread the language making people willing to learn it so as to function more on a global terrain. As the language spreads, its culture spreads along with it. English language has thus run across the globe stampeding languages and culture on its way because everybody wants to speak it and behave in consonance to its culture. This language has crossed many cultures devastating them and also grounding them to extinction.

Meanwhile, it is observed by UNESCO (2012) that "among the 6,000 languages and dialects of the world, $50 \%$ of them are threatened. A language disappears on every two weeks, carrying with it an entire cultural and intellectual heritage". Garrick and People (2003) also assert that languages estimated for extinction range from 4,000 to 9,000 since fifteenth $\left(15^{\text {th }}\right)$ century.

Globalization has therefore made it impossible for African nations to protect not only their culture but their territorial integrity. As English language claims dominance over other African languages, so also the English culture does, overwhelming the African culture. The world is porous and Africa is feeling the pain economically, socially and politically; no bound to what globalization via the internet can do to a feeble culture like African culture with the endangered languages.

It could be observed that globalization has brought a great change to human lives, it has forced certain languages over others thereby having loss of cultures, bringing about anti-social behaviours as people affected desperately try to preserve their languages. Globalization also aids loss of self esteem; it has marginalized some languages and caused death of some. Globalization has also promoted cultural imperialism because it aids the west in promoting and portraying its culture as having more worth or being more righteous and current than other regions' cultural values. The question that then readily comes to mind is: "is globalization moving the world inexorably toward an interconnected state with one economy, one language, and an education system with a similar pedagogy, organizational structure, universal curriculum, and dovetailing goals?" (Piper, 2006). This, definitely, is not in the best interests of Africa, its economy, and certainly not its education systems, at least not without some strong and significant caveats.

According to Carnoy and Photen, and Cheru, in Piper (2006):

The weight of evidence in Sub-Saharan Africa over the last 25 years suggests that globalization has not led to increased educational equity among countries in the region or even within the countries. Moreover, it has not drastically reformed pedagogy or increased student learning, and has not provided an influx of resources sufficient to create fundamental education expansion or improvement.

In the words of UNESCO, again as cited by Piper (2006), "globalization forces... have encouraged or even demanded education policies that have halted or reversed earlier gains in 
Ayodeji Olasunkanmi ABARI, Idowu Olufunke OYETOLA, Adedapo Adetayo OKUNUGA. Preserving African Languages and Territorial Integrity in the Face of Education and Globalization

\section{PROBLEMS \\ OF EDUCATION \\ IN THE $21^{\text {st }}$ CENTURY \\ Volume 57, 2013}

access to education, equity in its distribution, and a decrease in its quality, particularly at the secondary and tertiary levels

\section{Implications for African Languages and Territorial Integrity Maintenance}

It is very important that Africans should preserve their languages, globalization notwithstanding. African nations must provide the means by which their languages and cultures could be saved from complete extinction. This can be done by promoting the native languages both at home, the school and also in businesses and also promotes a very strong national identity. Ironically, hundreds of African languages have remained unstudied or poorly documented (Negash, 2005).

Governments in Africa should make their people appreciate the importance of their languages by appreciating it themselves. African governments should make serious and bold efforts to save those native languages in danger of extinction and at the same time preserve the cultures of those languages by all means. African governments should make serious and conscious efforts to develop their nations scientifically and technologically albeit along their own culture and tradition. It is however lamentable that the stymieing role of the African elite, including political leaders and university professors aid in sustaining Africa's linguistic disaster (Negash, 2005). Instead of investing in and using their linguistic, cultural, and human potential, African governments and the elite still continue to channel away their resources and energies into learning 'imperial' languages that are used by a tiny minority of the population (Negash, 2005).

Moreover, the adoption of international languages hook, line and sinker should be discouraged. Specific efforts should be made, therefore, to adapt the international languages and the developed science and technology of the language owners to suit the cultural and traditional purposes of Africans. In these ways, Africans can still maintain and retain their languages and integrity, be educated and be not left out of the globalization process. Thus, "Africa education systems should carefully pick and choose aspects of the globalization smorgasbord that are beneficial, and then politely or violently resist the rest" (Piper, 2006).

\section{Conclusions}

Today, more than ever before, it is realized and accepted the world over that there is a global trend toward an integrated economy which inevitably demands a common language that transcends boundaries. This trend, however, puts speakers of regional dialects and minority languages at a distinct disadvantage and at the threshold of extinction perhaps with the exception of those languages that have young people, business, and government on their side. That is, "significant global economic and structural realities make language preservation efforts increasingly difficult" (Corbin, 2007). Thus, "the realities of commerce and the seductive power of world population culture are placing pressure on speakers of minority languages to learn majority languages or suffer the consequences: greater difficulty doing business, less access to information..." (Garland, 2006). This is the fate of African languages which are now endangered in the face of globalization.

Globalization has indeed affected all spheres of human endeavours such as culture, trade, investment, natural environment, workforce, media, population growth, health, and so on. It has taken its toll on language, too. The increase in globalization has in many ways affected language both positively and negatively. These effects of language in turn affect the indigenous culture and language and also the education of Africans in many ways since language is a veritable means of education and of transmitting culture and tradition through the ages.

However, as observed by Mufwene (2002), "the future of languages in the twenty-first 
century obviously depends on how individual nations will evolve socio-economically during that time". Moreover, Mufwene (2002) continues, "from a purely academic perspective, language shift, endangerment and death are all part of language evolution". After all, "the relatively incidents of language loss also have precedents in older history. Like the enslaved Africans, the Jews enslaved in Babylon and Egypt had lost their language through absorption in the local socio-economic infrastructure, although they had a low social status and were not integrated" (Hagege, in Mufwene, 2002). Thus, African languages could still be preserved to be part of the present global affairs, they could still be made to thrive and gain a foothold, first in their native lands, and then elsewhere without necessarily being out of tune with the rest of the world. And, by implication, African languages could still play the dominant role in the education of Africans such that the territorial integrity of Africa and Africans is not lost to globalization. It is only a matter of awareness, consciousness, enlightenment and determination, partly on the part of the citizenry but mostly on the part of African governments. In the words of Garland (2006), "it is clear from several modern examples that a dying or dead language can turn around and become vibrant again, depending on people's determination and the government policies that are put in place".

\section{Recommendations}

In the light of the observations and discussions made above and earlier on in this paper, the following specific actions and steps are recommended for Africa and Africans:

1. Indigenous languages should be made a compulsory subject to be passed at the minimal level at all levels of education.

2. Indigenous languages should be made the medium of instruction in the early years of education, that is, basic classes $1-3$. This would enhance the educational, scientific and technological development of the people as it has done for the developed nations where the mother tongue is used as the basic language of instruction in schools. This was once practised in Nigeria, in the earlier days of western education in the country, and it worked. It is the practice in a few African countries where indigenous language is still the medium of instruction even up to the secondary level and an international language is only learnt as a second/foreign language as in Tanzania where Swahili is the initial medium of instruction in schools. In today's global world, the battle for the preservation of linguistic heritage is being fought less with arms and protests and more with computers and school rooms (Corbin, 2007).

3. Promotional activities should be undertaken in all spheres of life particularly in the communication world to project African indigenous languages, culture and tradition which are worthy of their values in civilization in the real context of the word, civilization that would bring about good behaviour and virtues not ones that would engender vices and obscenity. Towards this end, the opportunity offered by the International Mother Language Day (21 February) celebration should be seized and prominent activities like awareness campaign and information workshops for all and sundry be lined up by African countries to promote African indigenous languages.

4. Each and every African country should, as a matter of urgency, evolve a language policy that explicitly focuses on the drive for mother tongue education and the ever pressing need to be able to use an international language such as English. In other words, such a policy should be tailored towards the promotion of mother-tongue-based bilingual or multilingual approaches in education which helps in the preservation and promotion of indigenous languages while at the same time does not shut the door to globalization. Early bilingualism can help prepare young people to master several languages (Garland, 2006). 
Ayodeji Olasunkanmi ABARI, Idowu Olufunke OYETOLA, Adedapo Adetayo OKUNUGA. Preserving African Languages and Territorial Integrity in the Face of Education and Globalization

PROBLEMS

OF EDUCATION

IN THE $21^{\text {st }}$ CENTURY

Volume 57, 2013

5. A genuine African schooling system must be evolved that meets local (African) needs as opposed to those dictated by the global market economy. In this wise, the system must recast the philosophical foundations of African education and re-introduce indigenous ways of knowing to formal education curricula. The system must also re-organize to better reflect African realities and culture and fit the texture of children's lives and community realities (Piper, 2006).

6. The media should be given specific roles to play in this crucial matter as journalists and publishers are part and parcel of the knowledge chain and are central to the production and distribution of ideas. They should employ their communication skills in literal messages, expressions and ideas to promote and preserve indigenous languages. They should also have more programmes in local languages and on local radio and TV stations.

\section{References}

Al-Rodhan, N. R. F., \& Stoudmann, G. (2006). Definitions of globalization: A comprehensive overview and proposed definitions. Retrieved August 24, 2013 from www.sustainablehistory.com/articles/ definitions-of-globalization.pdf

Corbin, G. (2007). The challenges of language preservation. Retrieved December 1, 2013 from www. globalenvision.org/library/33/1472.

Ethusani, G. (2002). The plight of education and status of teachers in Nigeria: Issues and challenges. A paper presented at the forum on cost and financing of education in Nigeria, held in Abuja in September, 2002.

Federal Republic of Nigeria (2004). National policy on education. Lagos: NERDC Press.

Garland, E. (2006). Can minority languages be saved? Retrieved December 1, 2013 from www.wfs.org

Garrick, B., \& People J. (2003). Humanity: An introduction to cultural anthropology. Belmont: Thompson Learning, Inc.

Kiplangat, C. (2003). Our languages are dying. Retrieved August 24, 2013 from http://www.globalpolicy. org/globaliz/cultural/2003/0224 languages.htm.

Li, S. (2002). Globalization of languages. Retrieved August 24, 2013 from http://www.globalhawaii.org/ PDF/language.pdf.

Mufwene, S. S. (2002). Colonisation, Globalization, and the future of languages in the twenty-first century. MOST Journal of Multicultural Societies, 4 (2).

Negash, G. (2005). Globalization and the role of African languages for development. Retrieved November 24, 2013 from ies.berkeley.edu/...Colonial\%20Language\%20Conference\%20Papers/NE...

Piper, B. (2006). African education and globalization: Critical perspectives. Lanham, MD: Lexington Books.

Rabin, A. (2011). Language of instruction in Tanzania schools: Creating class divides and decreasing educational standards. Retrieved August 24, 2013 from www.thinkafricapress.com/tanzania/language-instruction-tanzania-schools-creating-class-divides-and-decreasing-educational-s

Taylor, S., \& Coetzee, S. (2013). Estimating the impact of language of instruction in South African primary schools: A fixed effects approach. Retrieved November 24, 2013 from www.essa2013.org. za/fullpaper/essa2013_2586.pdf

UNESCO (2013). Languages in education. Retrieved August 24, 2013 from www.unesco.org/new/en/ education/themes/strengthening-education-systems/languages-in-education/

UNESCO (2012). Education for sustainable development - preserving linguistic and cultural diversity. Retrieved August 24, 2013 from www./singleview/news/education_for_sustainable_development

Williams, E. (2004). Research and policy on language in education in Africa. Retrieved on November 24, 2013 from www.norrag.org/en/publications/norrag-news/online-version/language-politicsand-the-politics-of-language-in-education/detail/research-and-policy-on-lar 
Ayodeji Olasunkanmi ABARI, Idowu Olufunke OYETOLA, Adedapo Adetayo OKUNUGA. Preserving African Languages and Territorial Integrity in the Face of Education and Globalization

$$
\text { Advised by Angela James, University of KwaZulu - Natal, South Africa } \mid \begin{aligned}
& \text { PROBLEMS } \\
& \text { OF EDUCATION } \\
& \text { IN THE 21. CENTURY } \\
& \text { Volume 57, 2013 } \\
&
\end{aligned}
$$

E-mail: ayodeji.abari@yahoo.com

Idowu Olufunke Oyetola

PhD., Senior Lecturer, Department of Educational Management, Lagos State University, Ojo, Nigeria.

E-mail: funke.oyetola@yahoo.com

Adedapo Adetayo Okunuga

Lecturer, Department of Educational Management, Lagos State University, Ojo, Nigeria.

E-mail: agbeburu@yahoo.com 